\title{
Terreneuvian stratigraphy and faunas from the Anabar Uplift, Siberia
}

Artem Kouchinsky, Stefan Bengtson, Ed Landing, Michael Steiner, Michael Vendrasco, and Karen Ziegler

Acta Palaeontologica Polonica 62 (2), 2017: 311-440 doi:https://doi.org/10.4202/app.00289.2016

Assemblages of mineralized skeletal fossils are described from limestone rocks of the lower Cambrian Nemakit-Daldyn, Medvezhya, Kugda-Yuryakh, Manykay, and lower Emyaksin formations exposed on the western and eastern flanks of the Anabar Uplift of the northern Siberian Platform. The skeletal fossil assemblages consist mainly of anabaritids, molluscs, and hyoliths, and also contain other taxa such as Blastulospongia, Chancelloria , Fomitchella, Hyolithellus, Platysolenites, Protohertzina, and Tianzhushanella. The first tianzhushanellids from Siberia, including Tianzhushanella tolli sp. nov., are described. The morphological variation of Protohertzina anabarica and Anabarites trisulcatus from their type locality is documented. Prominent longitudinal keels in the anabaritid Selindeochrea tripartita are demonstrated. Among the earliest molluscs from the Nemakit-Daldyn Formation, Purella and Yunnanopleura are interpreted as shelly parts of the same species. Fibrous microstructure of the outer layer and a wrinkled inner layer of mineralised cuticle in the organophosphatic sclerites of Fomitchella are reported. A siliceous composition of the globular fossil Blastulospongia is reported herein and a possible protistan affinity similar to Platysolenites is discussed. New carbon isotope data facilitate correlation both across the Anabar Uplift and with the Terreneuvian Series of the IUGS chronostratigraphical scheme for the Cambrian System. The base of Cambrian Stage 2 is provisionally placed herein within the Fortunian-Cambrian Stage 2 transitional interval bracketed by the lowest appearance of Watsonella crosbyi and by a slightly higher horizon at the peak of carbon isotope excursion I' from western flank of the Anabar Uplift. Correlation across the Siberian Platform of the fossiliferous Medvezhya and lower Emyaksin formations showing 813 Ccarb excursion I' with the upper Sukharikha Formation containing excursion $5 p$ and upper Ust'-Yudoma Formation containing excursion I is supported herein.

Key words: Mollusca, stratigraphy, carbon isotopes, Cambrian, Terreneuvian, Russia, Siberia, Anabar.

Artem Kouchinsky [artem.kouchinsky@nrm.se] and Stefan Bengtson [stefan.bengtson@nrm.se ], Department of Palaeobiology, Swedish Museum of Natural History, Box 50007, SE-104 05 Stockholm, Sweden. Ed Landing [ed.landing@ nysed.gov ], New York State Museum, 222 Madison Ave, Albany, NY 12230, USA. Michael Steiner [michael.steiner@fu-berlin.de], Freie Universität Berlin, Malteserstrasse 74-100, Haus C Raum C.021, D-12249 Berlin, Germany. 
Michael Vendrasco [mvendrasco@pasadena.edu], Department of Geology, Pasadena

City College, 1570 E Colorado Blvd, Pasadena, CA 91106, USA. Karen Ziegler [kziegler@unm.edu], Institute of Meteoritics, 1 University of New Mexico, Albuquerque, NM 87131-0001, USA.

This is an open-access article distributed under the terms of the Creative Commons Attribution License (for details please see creativecommons.org), which permits unrestricted use, distribution, and reproduction in any medium, provided the original author and source are credited.

Fof Full text $(12,311.4 \mathrm{kB})$ ।

Fof 